\title{
The effect of age and occupation on the seroprevalence of Helicobacter pylori infection
}

\author{
GI Perez-Perez, DSc, T Marrie, MD, h Inouye, MD, T Shimoyama, MD, G Marshall, PhD, \\ $G$ MEIKLEJOHN, MD, MJ BLASER, MD
}

\begin{abstract}
Gi Perez-Perez, T Marrie, H Inouye, et al. The effect of age and occupation on the seroprevalence of Helicobacter pylori infection. Can J Infect Dis 1992;3(3):134-138. Serological studies in developed and developing countries using enzyme-linked immunosorbent assays have validated this technique as a rapid, noninvasive method for the diagnosis of Helicobacter pylori infections. The prevalence of serum antibodies to $H$ pylori was studied in 473 Canadian blood donors from Manitoba, 212 healthy Japanese, and 226 healthy Americans. As expected, the seroprevalence rose progressively with age in the three populations and reached its peak (greater than 55\%) in subjects 60 years of age and older. The seroprevalence did not decrease in elderly persons (60 to 99 years), indicating a persistent immune response. More detailed analysis was performed on the Canadian population. Age-adjusted prevalence rates in men and women were similar. Among young adults (15 to 29 years), farmers had a significantly higher seroprevalence rate than white-collar or blue-collar workers, but in older persons occupational rates were similar. A multiple linear regression analysis of the data confirmed that age and occupation in young adults were both significantly associated with seroprevalence of $\mathrm{H}$ pylori infections.
\end{abstract}

Key Words: ELISA, Epidemiology. Helicobacter pylori, Occupational risk, Serology, Seroprevalence

\section{Effet de l'âge et de la profession sur la prévalence de séropositivité des infections à Helicobacter pylori}

\begin{abstract}
RESUME: Des études sérologiques effectuées dans les pays développés et en voie de développement et utilisant les dosages immunoenzymatiques ont confirmé la valeur de cette méthode rapide et non envahissante dans le diagnostic des infections à Helicobacter pylori. On a étudié la prévalence des anticorps sériques à $H$ pylori chez 473 donneurs de sang canadiens originaires du Manitoba, 212 Japonais sains et 226 Américains sains. Comme on le supposait, la prévalence de séropositivité augmente progressivement avec l'âge dans les trois populations et elle atteint son pic (supérieure à $55 \%$ ) chez les sujets âgés de 60 ans et plus. La prévalence de séropositivité n’augmente pas chez les personnes âgées (60 à 99 ans), ce qui indique une réponse immune persistante. Une analyse plus détaillée a été effectuée parmi la population canadienne. Les taux de prévalence modifiés en fonction de l'âge chez l'homme et chez la femme sont similaires. Parmi les jeunes adultes (de 15 à 29 ans), la prévalence de séropositivité était significativement plus élevée chez les agriculteurs par rapport aux employés de bureau et aux ouvriers; mais chez les personnes plus âgées, les taux étaient similaires quel que soit le métier. Une analyse de régression linéaire multiple des données confirme que l'âge et la profession des jeunes adultes présentent chacun un lien significatif avec la prévalence de séropositivité des infections à $H$ pylori.
\end{abstract}

Divisions of Infectious Diseases, Vanderbilt University School of Medicine and Veterans Administration Medical Center, Nashville, Tennessee, USA; Division of Infectious Diseases, Dalhousie University, Halifax, Nova Scotia; Hyogo College of Medicine, Nishinomiya, Japan; Departamento de Estadistica, Pontificia Universidad Católica de Chile, Santiago, Chile; and Division of Infectious Diseases, University of Colorado School of Medicine, Denver, Colorado, USA

Correspondence and reprints: Dr Guillermo I Perez-Perez, Infectious Diseases Division, Department of Medicine, Vanderbilt University School of Medicine, Nashville, TN 37232, USA

Received for publication November 20, 1990. Accepted April 13, 1991 
$\mathrm{T}$ HE PRESENCE OF HELICOBACTER (FORMERLY CAMPYLObacter [1]) pylori in the stomach of persons with active chronic gastritis and peptic ulcer disease has led to substantial interest in this bacterium (2-4). An increasing body of evidence indicates that $H$ pylori is involved in the etiology of active chronic gastritis and possibly in duodenal ulceration (3). Virtually all in fected persons mount a specific systemic humoral immune response to the organism (4-7), a phenomenon that has allowed the development of diagnostic tests that do not require endoscopic examination of the subject. In addition to their use in diagnosing infection, serological tests can be used to gain knowledge of the epidemiology of the infection. Although much has been learned recently about $H$ pylori epidemiology (5,8-14), the use of a variety of different assays, not all of which have been rigorously validated, has limited interpretation of the data.

This study used a single, previously validated enzyme-linked immunosorbent assay (ELISA) of high sensitivity and specificity $(4,5,10)$ to compare $H$ pylori antibody prevalence in populations of adults from three developed countries: Canada, the United States of America and Japan. In the Canadian population, the effects of age, gender and occupation on the prevalence of $H$ pylori antibodies were also examined.

\section{MATERIALS AND METHODS}

Population: Serum specimens were collected from 901 healthy persons. There were 473 blood donors from Manitoba, Winnipeg (aged 19 to 65 years, including 26 persons who were older than 60 years). The blood donors were from farms (34.2\%), towns (48.9\%) or cities (15.9\%), as previously described (15). From this population, information on gender and occupation was also tabulated. There were 212 persons from Hyogo, Japan (aged 15 to 90 years, including 20 older than 60 years). There were 226 persons from Colorado (aged 15 to 59 years including 101 nursing home residents older than 60 years). The populations from Hyogo and Colorado were from the Kobe and Denver metropolitan areas, respectively, and both represented urban populations. No endoscopic information was available about any of the subjects. All sera had been stored at $-20^{\circ} \mathrm{C}$ for at least six months.

ELISA for $\boldsymbol{H}$ pylori antibodies: Sera were examined for $H$ pylori-specific IgG antibodies by ELISA, as previously described (5). The screening serum dilution was 1:800. To establish a threshold for positivity in the IgG ELISA, criteria previously described were used (10). In brief, the mean optical density for sera from 35 healthy children under 10 years of age was determined. A positive result for an unknown sample was then defined as having an optical density value more than the mean plus three intervals of standard deviation of the values obtained for the children's sera. Using linear regression, a threshold was calculated for each day's run based on the mean optical density value of four control sera that had been simultaneously run with the children's sera, as previously described (10). If the ratio of the optical density value of the unknown sample to the calculated threshold for that day's run was greater than 1.0, the sample was considered positive. All assays were done in duplicate on at least two separate days. The intra- and interassay variations in optical density of positive and negative control sera were less than $5 \%$.

Statistical methods: The $\chi^{2}$ test was used for univariate analysis of statistical significance of different rates of positivity among subgroups of the population studied. Multiple analysis of covariance (16) was used to determine correlates of $H$ pylori antibodies while controlling for other potentially confounding factors.

\section{RESULTS}

Prevalence of $\boldsymbol{H}$ pylori-specific serum IgG antibodies: In each of the populations tested, there was a relatively low seroprevalence of $H$ pylori infection during the first three decades of life. However, seroprevalence rose progressively with age in each population, reaching the highest point by the sixth decade of life (Figure 1). Using a $\chi^{2}$ test of trend the authors found that a significant trend in the prevalence of infection was present in each of the three countries $(\mathrm{P}<0.02)$. If the last age category in Figure 1 is excluded from analysis, no significant trend was found in any country, but if the data are combined from the three countries, the trend is borderline significant $(\mathrm{P}=0.056)$.

Persistence of $\boldsymbol{H}$ pylori-specific antibodies in elderly persons: The prevalence of specific IgG did not decrease in persons aged 60 to 99 years (Table 1). Elderly persons (older than 60 years) living in nursing homes or in family settings had similar seroprevalences (70 versus $65 \%$ ). Moreover, the age-specific seroprevalence rates were similar in the three populations (Japan, Canada and USA) (data not shown).

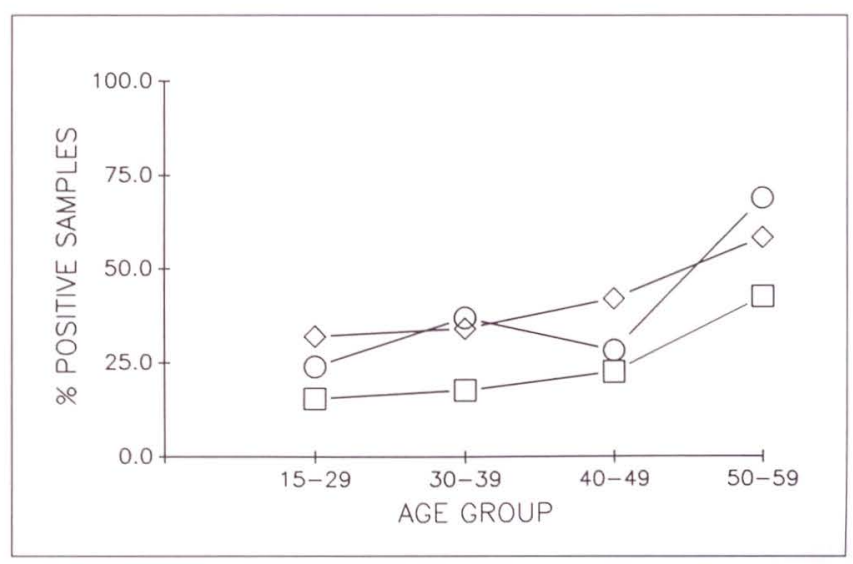

Figure 1) Prevalence of Helicobacter pylori-specific IgG antibodies measured by enzyme-linked immunosorbent assay in healthy populations by age. Manitoba $n=447(0)$ : Colorado $n=125$ (1); Hyogo $n=192$ (o) 


\section{TABLE 1}

Prevalence of Helicobacter pylori-specific serum IgG in 147 elderly persons in Japan, Canada and the United States

\begin{tabular}{lcc}
\hline Age group & Number of persons studied & $\%$ positive \\
\hline 60 to 69 years & 46 & 67.4 \\
70 to 79 years & 40 & 62.5 \\
80 to 89 years & 34 & 64.7 \\
$\geq 90$ years & 27 & 85.2 \\
Total & 147 & 69.9 \\
\hline
\end{tabular}

Relation of $\boldsymbol{H}$ pylori infection with gender: Of the 473 Canadian blood donors, the seroprevalence of $H$ pylori infection was studied in 469 subjects in whom gender was known (256 men and 213 women). A significantly higher proportion of women were positive for $\mathrm{H}$ pylorispecific IgG than were men ( 41 versus $28 \%$; $\mathrm{P}=0.007$ ); however, when data from the groups were age-adjusted no significant difference remained.

Influence of occupation on $\mathrm{H}$ pylori infection rates: Among the Canadian subjects, information regarding employment and occupation were available for 466 persons. Not surprisingly, based on their age, retired persons had the highest seroprevalence of $H$ pylori infection (Table 2). The homemaker group had a high seroprevalence similar to that of the farmer group, but when results were age-adjusted there was no significant association. Among working age persons 15 to 39 years old, the highest seroprevalence of $H$ pylori infection was in farmers $(52 \%)$. In contrast, seroprevalence in other occupational groups remained low during the third and fourth decades of life, and only increased in the fifth decade. After correction for age, white- and blue-collar workers had slightly lower seroprevalence rates than other occupational groups. Multiple variant analysis of these data confirmed that age was significantly as-

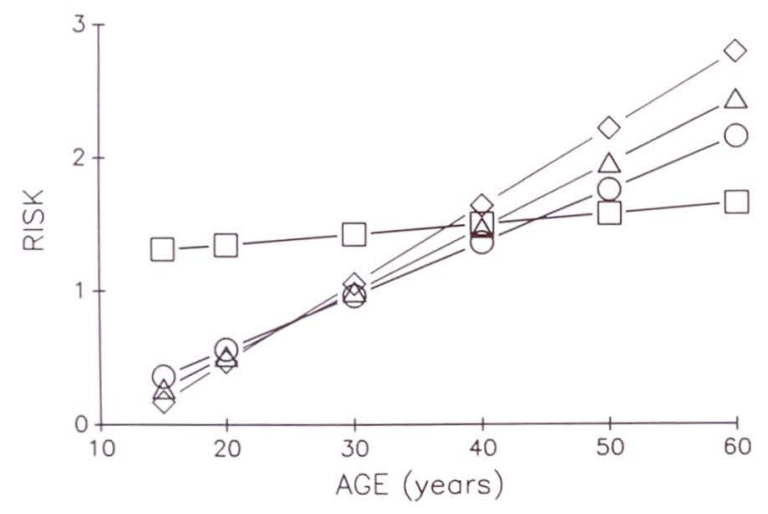

Figure 2) Risk of infection with Helicobacter pylori among 466 healthy blood donors from Manitoba according to age and occupation: white-collar $b=0.04 \pm 0.01$ (0); blue-collar $b=0.05 \pm 0.01$ $(\Delta)$; farmer $b=0.008 \pm 0.01(\square)$; homemaker $b=0.06 \pm 0.01(0)$. The $b$ values represent the incremental gain in infection rate with each year's increment in age

\section{TABLE 2}

Comparison of Helicobacter pylori-specific IgG antibody prevalence among Manitoban blood donors in relation to occupation

\begin{tabular}{lcc}
\hline Occupation & Number of persons studied & $\%$ positive \\
\hline White-collar & 180 & 36.7 \\
Blue-collar & 101 & 33.7 \\
Farmer & 90 & 50.0 \\
Homemaker & 89 & 45.0 \\
Retired & 6 & 66.6 \\
\hline
\end{tabular}

sociated with $H$ pylori infection, and that the farmers were at risk for infection at a younger age than the other groups (Figure 2).

\section{DISCUSSION}

Age has been the single most important determinant of the prevalence of $H$ pylori antibodies in studies of healthy populations $(9,12,17,18)$. However, comparisons of different populations has been difficult because a variety of serological assays were employed. In this study using a single, well validated assay $(4,5,9,10)$ to determine seropositivity in populations from three developed countries, the authors observed a progressive age-related increase in the prevalence of $H$ pylori antibodies that was similar in the three populations. Although subjects under 15 years of age were not included, the trend of seroprevalence by age in the populations studied was similar to the rates observed in asymptomatic volunteers from several developed countries who underwent endoscopy $(4,19-21)$, corroborating the lack of significant artefact in the volunteer studies. In developed countries, $H$ pylori infection is uncommon early in life; the progressive increases suggest that most transmission probably occurs during the third through sixth decades of life. In developing countries, transmission is apparently more intense and occurs earlier $(8,9)$. Similar to the previous studies $(5,6)$, the present authors found no gender-related differences in seroprevalence of $H$ pylori infection when a multiple variant analysis was performed.

A decline in the prevalence of detectable antibodies, as well as a decline in natural immunity to some infectious agents, has been reported to occur with ageing $(22,23)$. However, the present study found that the prevalence of antibodies to $H$ pylori remained high and stable in persons 60 to 99 years old. This finding suggests that $H$ pylori infection persists for many years, perhaps for life, in most infected persons, and that infection is associated with chronic antigenic stimulation. The alternative hypothesis is that antibodies persist despite clearance of infection. Although this may be possible for brief periods following clearance, studies of antibiotic treatment of $H$ pylori infection indicate that when the infection is eradicated antibodies diminish (24), as conventional B cell theory suggests (25). 
Several authors have suggested that certain occupations may be associated with an increased risk of $H$ pylori infection (26-30). Vaira et al (31) demonstrated that abattoir workers had significantly higher infection rates than other workers, but no information was provided on ethnicity or other socioeconomic factors. As previously reported in blood donor populations (26-32), age was strongly associated with the presence of $H$ pylori infection. In the present study, occupation was associated with the presence of infection after controlling for gender and age, suggesting that certain activities may be associated with a higher risk of $H$ pylori infection than others. Using multiple analysis of covariance, farmers were more likely to be infected than were

ACKNOWLEDGEMENTS: This work was supported in part by the Medical Research Service of the Veterans Administration, and by the Procter and Gamble Company. We thank Kim Le for technical assistance.

\section{REFERENCES}

1. Goodwin CS, Armstrong JA, Chilvers T, et al. Transfer of Campylobacter pylori and Campylobacter mustelae to Helicobacter gen. nov. as Helicobacter pylori comb. nov. and Helicobacter mustelae comb. nov. respectively. Int J Syst Bacteriol 1989;39:397-405.

2. Marshall BJ, Warren JR. Unidentified curved bacilli in the stomach of patients with gastritis and peptic ulceration. Lancet 1984:i:1311-5.

3. Blaser MJ. Helicobacter pylori and the pathogenesis of gastroduodenal inflammation. J Infect Dis 1990;161:626-33.

4. Dooley CP, Cohen H, Fitzgibbons PL, et al. Prevalence of Helicobacter pylori infection and histologic gastritis in asymptomatic persons. N Engl J Med 1989;321:1562-6.

5. Perez-Perez GI, Dworkin BM, Chodos JE, Blaser MJ. Campylobacter pylori antibodies in humans. Ann Intern Med 1988;109:11-7.

6. Hirschl AM, Rathbone BJ, Wyatt JI, Berger J, Rotter ML. Comparison of ELISA antigen preparations alone or in combination for serodiagnosing Helicobacter pylori infections. J Clin Pathol 1990;43:511-3.

7. Rathbone BJ, Wyatt JI, Worsley BW, Trejdosiewcz LK, Heatley RV, Losowsky MS. Immune response to Campylobacter pyloridis. Lancet 1985;i:1217.

8. Megraud F, Brassens-Rabbe MP, Denis F, Belbouri A, Hoa DQ. Seroepidemiology of Campylobacter pylori infection in various populations. J Clin Microbiol 1989;27:1870-3.

9. Perez-Perez GI, Bodhidatta L, Wongsrichanalai J, et al. Seroprevalence of Helicobacter pylori infections in Thailand. J Infect Dis 1990;161:1237-41.

10. Drumm BE, Perez-Perez GI, Blaser NJ, Sherman P. Intrafamilial clustering of helicobacter infections. N Engl J Med 1990;322:359-63.

11. Mitchell. HM, Lee A, Berkowicz J, Borody T. The use of serology to diagnose active Campylobacter pylori infection. Med J Aust 1988;149:604-8.

12. Jones DM, Eldridge J, Fox AJ, Sethi P, Whorwell PJ. Antibody to the gastric campylobacter-like organism (Campylobacter pyloridis) - Clinical correlations and distribution in the normal population. J Med Microbiol 1986;22:57-62.

13. Dwyer B, Kaldor J, Tee W, Marakowski E, Raios K. Antibody response to Campylobacter pylori in diverse the other occupational groups studied, an effect due mostly to high rates among young farmers. There is no information on the specific nature of the farm exposures to determine the potential source for this early transmission. Ethnic status $(8,9,13,14,33,34)$ may be related to the seroprevalence of $H$ pylori infection, or perhaps residence (ie, urban, suburban, rural) and not occupation is the important factor in acquisition of $H$ pylori infection. Unfortunately, the present study lacked the demographic data to evaluate this hypothesis; however, the population of Manitoba is predominantly Caucasian. Nevertheless, a possible confounding role of ethnicity and residence on occupational association with $H$ pylori infection cannot be ruled out.

ethnic groups. Scand J Infect Dis 1988;20:349-50.

14. Polish LB, Douglas JM, Davidson AJ, Perez-Perez GI,

Blaser MJ. Characteristics of risk factors for Helicobacter pylori infection among men attending a sexual transmitted disease clinic: Lack of evidence for sexual transmission. J Clin Microbiol 1991;29:2139-43.

15. Marie TJ. Seroepidemiology of $Q$ fever in New Brunswick and Manitoba. Can J Microbiol 1988;34:1043-5.

16. SAS Institute Inc. SAS User's Guide: Statistics, version 5 edn. Cary: SAS Institute Inc, 1985.

17. Perez-Perez GI, Dunn BE. Diagnosis of $C$ pylori infection by serologic methods. In: Blaser MJ, ed. Campylobacter pylori in Gastritis and Peptic Ulcer Diseases. New York: Igaku-Shoin, 1989:163-74.

18. Parsonnet J. The epidemiology of $C$ pylori. In: Blaser MJ, ed. Campylobacter pylori in Gastritis and Peptic Ulcer Diseases. New York: Igaku-Shoin, 1989:51-60.

19. Rauws EA, Langenberg W, Houthoff HJ, Zanen HC, Tytgat GN. Campylobacter pylori-associated chronic active antral gastritis: A prospective study of its prevalence and the effects of antibacterial and antiulcer treatment. Gastroenterology 1988;94:33-40.

20. Barthel JS, Westblom TU, Havey AD, Gonzalez F, Everett ED. Gastritis and Campylobacter pylori in healthy asymptomatic volunteers. Arch Intern Med 1988; 148:1149-51.

21. Gregson DB, Low DE, Cohen MM, et al. The prevalence of Campylobacter pylori gastritis among asymptomatic adults. Can Med Assoc J 1989;140:1449-53.

22. Kay MB. Aging and the decline of immune responsiveness. In: Fudenberg HH, Stites DP, Caldwell JL, et al, eds. Basic and Clinical Immunology. Los Alteros: Lange Medical Publications, 1967:267-78.

23. Nordenstam G, Andersson B, Bengtsson C, et al. Age-related change in anticarbohydrate antibody levels. Am J Epidemiol 1989;129:89-96.

24. Vaira D, Holton J, Cairns SR, et al. Decreased antibody titers to Campylobacter pylori after treatment for gastritis. Br Med J 1988;97:397.

25. Gray D, Skarvall H. B-cell memory is short-lived in the absence of antigen. Nature 1988;336:70-3.

26. Morris A, Nicholson G, Lloyd G, Haines D, Rogers A, Taylor D. Seroepidemiology of Campylobacter pyloridis. N Z Med J 1986;99:657-9.

27. Morris A, Lloyd G, Nicholson G. Campylobacter pyloridis serology among gastroendoscopy clinic staff. N Z Med J 1986;99:820.

28. Sitas F, Forman D, Yarnell JWG, et al. Helicobacter pylori infection rates in relation to age and social class in a population of Welsh men. Gut 1991;32:25-8. 
29. Rawles JW, Harris ML, Paull G, et al. Antibody to Campylobacter pyloridis in endoscopy personnel, patients and controls. Gastroenterology 1987;92:1589. (Abst)

30. Bamwell NH. The prevalence of Campylobacter pylori gastritis among asymptomatic adults. Can Med Assoc $\mathrm{J}$ 1989;141:276. (Lett)

31. Vaira D, D'Anastasio C, Holton J, et al. Campylobacter pylori in abattoir workers: Is it a zoonosis? Lancet 1988:ii:725-6.

32. Kosunen TU, Hook J, Rautelin HI, Myllyla G. Age- dependent increase of Campylobacter pylori antibodies in blood donors. Scand J Gastroenterol 1989;24:110-4.

33. Graham DY, Klein PD, Opekun AR, et al. Epidemiology of Campylobacter pylori infection: Ethnic considerations. Scand J Infect Dis 1988;23:9-13.

34. Dehesa M, Dooley CP, Cohen H, Fitzgibbons P, Perez-Perez GI, Blaser MJ. High prevalence of Helicobacter pylori infection and histologic gastritis in asymptomatic Hispanic. J Clin Microbiol 1991;29:1128-31. 


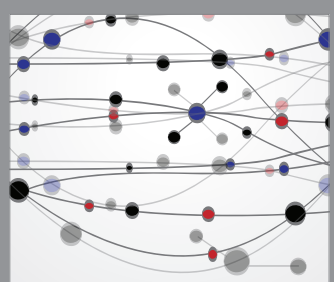

The Scientific World Journal
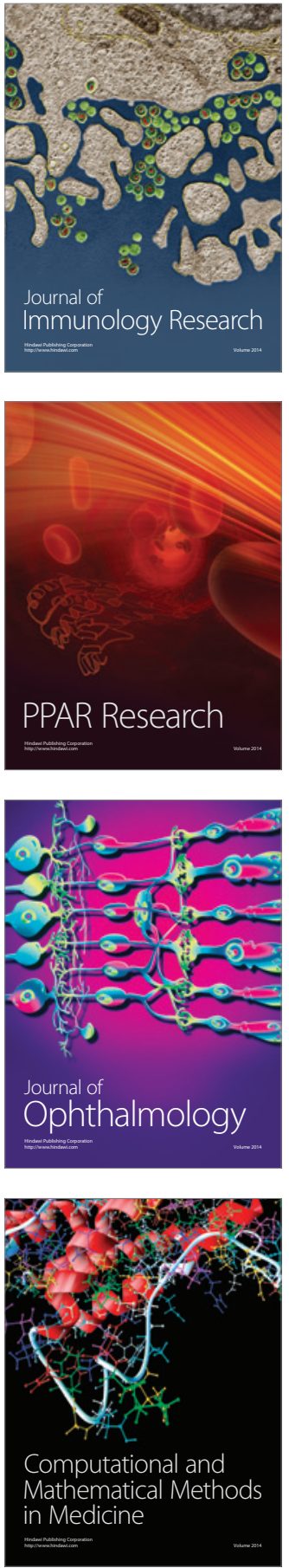

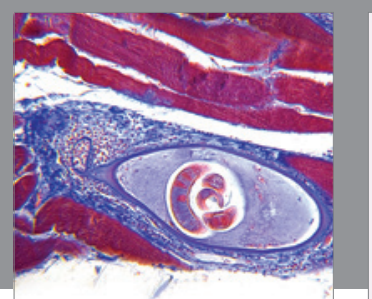

Gastroenterology Research and Practice

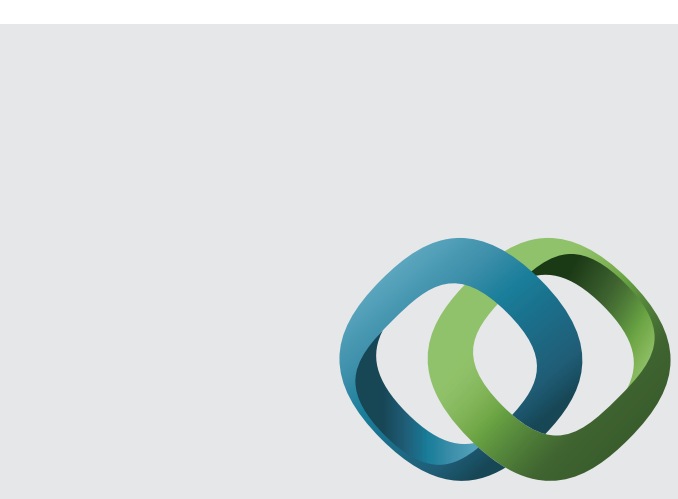

\section{Hindawi}

Submit your manuscripts at

http://www.hindawi.com
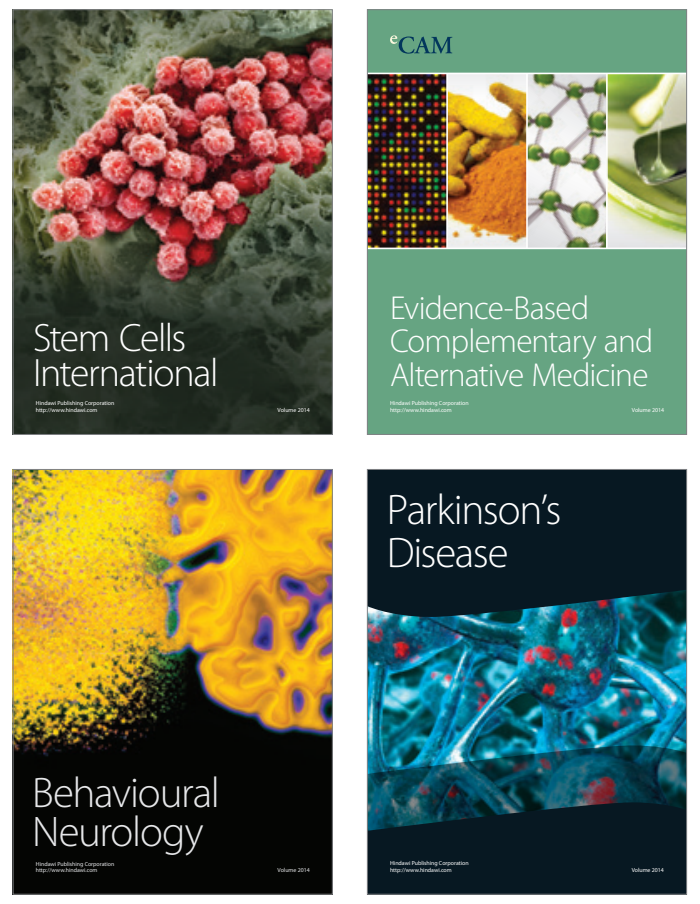
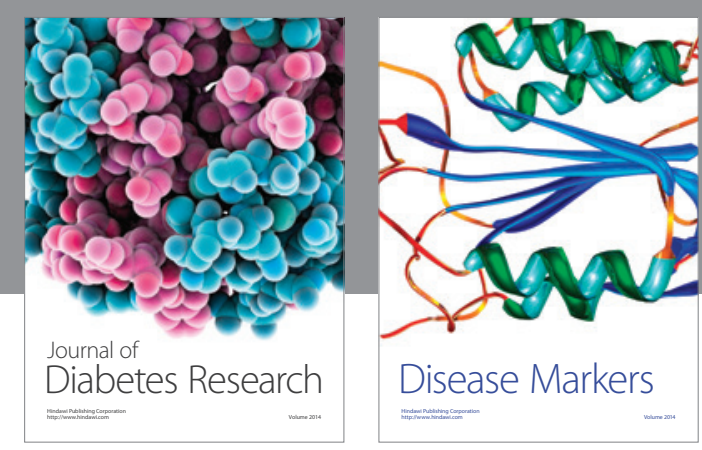

Disease Markers
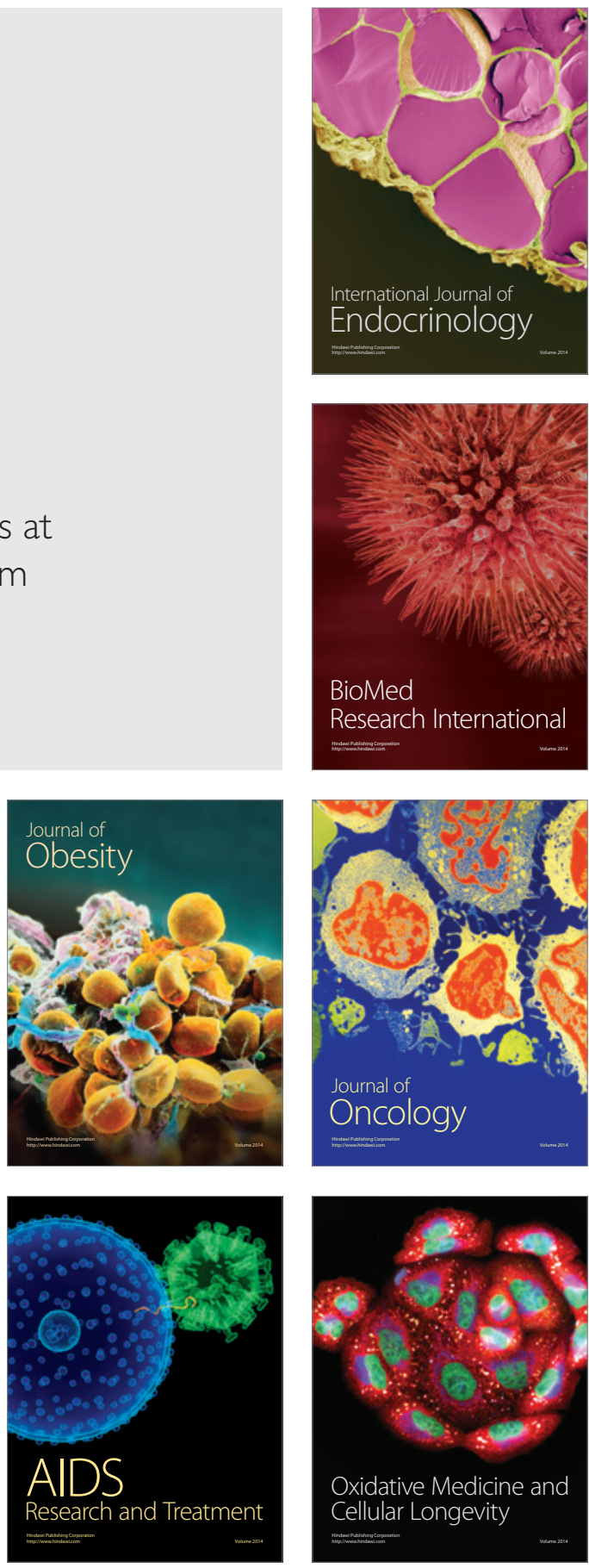